\title{
Desiccation tolerance in seeds of Annona emarginata (Schldtl.) H. Rainer and action of plant growth regulators on germination
}

\author{
Jaqueline Malagutti Corsato ${ }^{1 *}$, Gisela Ferreira ${ }^{1}$, Claudio Jose Barbedo² \\ 'Botany Department of the Biosciences Institute, Universidade Estadual de São Paulo (UNESP), Botucatu, SP, Brazil. \\ ${ }^{2}$ Seed Department of the Institute of Botany, São Paulo, SP, Brazil. \\ Corresponding author: jaque_corsato@hotmail.com
}

Received: 14 September 2012; Accepted: 24 January 2013

\begin{abstract}
Annona emarginata (Schldtl.) H. Rainer ("araticum-de-terra-fria") is used as a rootstock for several species of Annonaceae. It is suggested that these seeds should be sown immediately after extraction and, therefore, they could be intolerant to desiccation. There are several mechanisms involved with desiccation tolerance. Soluble sugars, for example, can accumulate and act as osmoprotectants for the membrane system during desiccation. The aim of this study is to assess desiccation tolerance in $A$. emarginata seeds. In addition, we examined the soluble sugars involved in desiccation tolerance. Finally, we determined the effect of gibberellic acid $\left(\mathrm{GA}_{4+7}\right)$ and $\mathrm{N}$-(phenylmethyl)-aminopurine in promoting the germination of seeds with different water contents. The experiment consisted of a randomized $4 \times 5$ factorial design (desiccation levels $x$ concentration of growth regulators). After drying, seeds containing 31 (control), 19, 12 and $5 \%$ water were incubated in different concentrations of $\mathrm{GA}_{4+7} \mathrm{~N}$-(phenylmethyl)-aminopurine $\left(0,250,500,750\right.$ and $\left.1000 \mathrm{mg} \mathrm{L}^{-1}\right)$ for 60 hours. The experiment was conducted in a germination chamber with alternating temperature and photoperiod of $20^{\circ} \mathrm{C}$ for 18 hours of darkness and $30^{\circ} \mathrm{C}$ for 6 hours of light. We analyzed electrical conductivity, germination rate, mean germination time, germination speed, frequency and uniformity of germination, percentage of dormant seeds and soluble sugar profile in intact seeds through high-performance liquid chromatography (HPLC). The data were subjected to analysis of variance, and the means were compared using Tukey's test at a threshold of $p<0.05$. The results showed that seeds of $A$. emarginata appears to be desiccation tolerant and, also, that sucrose increases when seed water content is reduced to values as low as $12 \%$, exogenous $\mathrm{GA}_{4+7}+\mathrm{N}$-(phenylmethyl)-aminopurine improves its germinability.
\end{abstract}

Keywords: Araticum-de-terra-fria, desiccation, cytokinins, gibberellins, soluble sugars.

\section{INTRODUCTION}

The capacity to control the physiological changes that occur during seed desiccation and storage is important to maintain germplasm banks. These strategies ensure plant germination over time and species preservation (Barbedo et al., 2002; Carvalho and Nakagawa, 2000).
Seeds have been classified based on their sensitivity to desiccation into desiccation-tolerant and desiccationintolerant categories (Roberts, 1973). Afterwards, desiccation tolerance was considered as a continuous variable, rather than a categorical one (Walters, 2000).

Orthodox seeds are those that are tolerant to desiccation. These seeds undergo pre-programmed 
desiccation during the final stage of maturation. Desiccation may be important to redirect seed metabolism towards germination (Black and Pitchard, 2002). When dry, these seeds reduce their metabolic rate. The desiccation allows them to be stored at low temperatures for long periods of time until the environmental conditions become favorable for germination (Kermode, 1990; Walters, 2000).

In contrast, desiccation-intolerant seeds do not reduce their water content at the end of development. Recalcitrant seeds are dispersed with high water content and full germinating capacity. In fact, these seeds may germinate while they are still connected to the mother plant (Pamenter and Berjak, 2000).

Certain prerequisites are necessary for seeds to tolerate the loss of $90-95 \%$ of their water content during the final stage of maturation. For example, soluble sugars protect the seed's cells (Walters, 2000; Moore et al., 2009). These compounds have hydrophilic properties. They act as osmoprotectants during water loss and help prevent membrane damage when water is plentiful (Koster and Leopold, 1988; Pammenter and Berjak, 2000).

Sucrose is a major sugar found in mature seeds and can act as a substrate for metabolism, or it can have protective effects on the cell membrane when it is present at high concentrations (Uemura and Steponkus, 2003). Raffinose and stachyose are two other sugars that are associated with desiccation tolerance, which may be stored during seed development (Peterbauer and Richter, 2001).

Even though the mechanisms of desiccation tolerance have been for long under investigation, there are few reports in literature on this topic in Annonaceae. Carvalho et al. (2001) assessed the desiccation tolerance of Annona glabra L. seeds. They observed that these seeds tolerated up to $3.8 \%$ of water reduction. After 365 days of storage, $90 \%$ of the seeds could still germinate.

The mechanisms involved in the desiccation tolerance of the species Annona emarginata (Schldtl.) H. Rainer (synonymy Rollinia sp.) (Rainer, 2007) are unknown. However, seed germination in this species is reduced to $20-30 \%$ after $2-3$ months of storage (Tokunaga, 2000).

Researchers are interested in studying this species because itcan be used as a rootstockfor other species, such asatemoya (AnnonacherimolaMill.XAnnonasquamosaL.) and cherimoya (Annona cherimola Mill.). The use of graft and the rootstock more compatible enables the plants more vigorous and resistant to fungi and insects (Kavati, 1997; Bonaventure, 1999; Tokunaga, 2000).
In addition to the difficulties to store the $A$. emarginata seeds, the germination process of the Annonaceae seeds is slow and uneven (Rizzini, 1973; Tokunaga, 2000). Pawshe et al. (1997) and Smet et al. (1999) have suggested that the germination of these seeds may be affected by the presence of abscisic acid in the embryo. Furthermore, integumentary impermeability and resistance may be important in this process. Thus, it may be important to use growth regulators in Annonaceae (Ferreira et al., 2002; Stenzel et al., 2003; Ferreira, 2011). Costa (2009) and Ferreira et al. (2006) observed that the seeds of $A$. emarginata and atemoya are permeable to water, but the movement of water is slow.

Overall, plant growth regulators, such as gibberellins and cytokinins, have been shown to favor the germination of Annonaceae seeds. Oliveira et al. (2010) found that the application of $778 \mathrm{mg} \mathrm{L}^{-1}$ of gibberellic acid $\left(\mathrm{GA}_{3}\right)$ increased the germination of atemoya seeds by $85.5 \%$. Costa et al. (2011) tested mixtures of growth regulators and observed satisfactory responses with the use of $\mathrm{GA}_{4+7}+\mathrm{N}$-(phenylmethyl)-aminopurine $\left(\mathrm{GA}_{4+7}+\mathrm{CK}\right)$ in A. emarginata seeds. The greatest germination rate was associated with $600 \mathrm{mg} \mathrm{L}^{-1}$ of the growth regulator, alternating temperatures of $20 / 30^{\circ} \mathrm{C}$ and alternating light $(37 \%)$ and dark $(32 \%)$ conditions. The water-imbibed seeds exhibited germination rates of 27 and $25 \%$ under light and dark conditions, respectively.

In this context, understanding the mechanisms underlying desiccation tolerance in $A$. emarginata seeds, and the stimuli that improve germination rates may increase the time that the seeds can be stored before viability is compromised. This information can remove the seasonal seedling production restrictions, as reported by Tokunaga (2000).

Therefore, the aim of this study was to assess the desiccation tolerance of Annona emarginata (Schldtl.) $\mathrm{H}$. Rainer seeds, changes in the content of soluble sugars and the effect of $\mathrm{GA}_{4+7} \mathrm{~N}$-(phenylmethyl)-aminopurine in promoting the germination of seeds subjected to different levels of desiccation.

\section{MATERIAL AND METHODS}

The fruits of Annona emarginata (Schltdl.) $\mathrm{H}$. Rainer ("araticum-de-terra-fria") were obtained from 20 matrices at the Integral Technical Assistance Coordination (Coordenadoria de Assistência Técnica Integral - CATI) in the municipality of São Bento do Sapucaí, São Paulo (SP) (latitude $22^{\circ} 41^{\prime} 20^{\prime \prime} S$ and longitude $45^{\circ} 43^{\prime} 51^{\prime \prime} \mathrm{W}$ ). The 
dried specimens were deposited at the BOTU herbarium of Universidade Estadual de São Paulo (UNESP) in Botucatu, SP, Brazil.

After the harvest, yellow fruits were collected after dispersion (when the fruit was no longer connected to the mother plant). These fruits were kept in dark polyethylene bags at room temperature $\left(25 \pm 3^{\circ} \mathrm{C}\right)$ for seven days to ferment. Next, the pulp was removed from the fruits by hand under running water with the help of a sieve. The seeds were decontaminated with a $2 \%$ antifungal solution (N-trichloromethylthio-4cyclohexene-1, 2-dicarboximide - Captan $^{\circledR}$ ) for 10 minutes and a $2 \%$ antibacterial solution (oxytetracycline hydrochloride - Terramycin ${ }^{\circledR}$ ) for 20 minutes.

Desiccation tolerance: After the seeds were extracted, they were washed under running water. The seeds' outer integument was softly dried. The water content of the seeds was determined by dehydrating them in an oven at $105 \pm 3^{\circ} \mathrm{C}$ for 24 hours. The results are expressed as a percentage of the wet seed weight (Brasil, 2009).

The seeds were then dried in a forced-air circulation oven at $50^{\circ} \mathrm{C}$ to adjust different desiccation levels artificially: 31 (control), 19, 12 and 5\%. After the desiccation levels were achieved, the seeds were incubated in a solution of gibberellin plus cytokinin $\left(\mathrm{GA}_{4+7}+\mathrm{CK}\right)$ Promalin ${ }^{\circledR}$ at concentrations of 0 (control), 250, 500, 750 and $1000 \mathrm{mg} \mathrm{L}^{-1}$ for 60 hours under constant aeration (Costa, 2011). These concentrations were calculated taking into account the real concentration of $\mathrm{GA}_{4+7}+\mathrm{CK}(1,8 \% \mathrm{w} / \mathrm{v})$.

Seeds were subsequently placed in rolls of 'germitest' paper moistened with distilled water at a ratio of 2.5 times its dry weight (Brasil, 2009). The experiment was kept in a germination chamber with alternating temperatures and photoperiod of $20^{\circ} \mathrm{C}$ for 18 hours of darkness and $30^{\circ} \mathrm{C}$ for 6 hours of light (Costa et al., 2011).

The number of germinated seeds was scored daily. Seeds were considered as germinated when its protruded primary root was more than two millimeters long (Bewley and Black, 2013). At the end of the experimental period, non-germinated were subjected to the tetrazolium test and the percentage of both dead and living dormant seeds were determined (Brasil, 2009).

The germinability parameters included germination percentage, mean germination time, germination speed, frequency, and uniformity of germination (Labouriau, 1983; Silva and Nakagawa, 1995; Ranal and Santana, 2006).
Next, we assessed membrane damage during desiccation by analyzing the electrical conductivity of leached electrolytes using the mass method. We applied a completely randomized experimental design. We analyzed four treatments consisting of the different levels of desiccation $(31,19,12$ and $5 \%$ ) and four replications of the 50 seeds in each experimental unit. The seeds were placed in $200 \mathrm{~mL}$ plastic cups containing $75 \mathrm{~mL}$ of deionized water. The seeds were left to imbibe in a germination chamber at $25^{\circ} \mathrm{C}$ for 24 hours (Brasil, 2009). Afterwards, the samples were removed from the incubator. The conductivity was measured using a desktop conductivity meter. During measurement, the seeds were carefully stirred to homogenize the leached electrolytes in the solution. The results are expressed in $\mu \mathrm{S} \mathrm{cm}^{-1} \mathrm{~g}^{-1}$ (Barbedo and Cicero, 1998; Vieira and Krzyzanowski, 1999).

Analysis of soluble sugars: Following the artificial desiccation procedures, whole $A$. emarginata seeds were placed in polyethylene bags for sugar analysis. Next, the intact seeds were wrapped with aluminum foil and frozen in liquid nitrogen. After freezing, samples were stored at $-80^{\circ} \mathrm{C}$ until processing.

To extract the soluble sugars, a $70 \%$ ethanol solution was added to $100 \mathrm{mg}$ of each sample. This mixture was subsequently boiled three times in ethanol for five minutes (Durda et al., 2007). The extracts were centrifuged at $3,000 g_{n}$ and $20^{\circ} \mathrm{C}$ for 10 minutes, being then filtered. The soluble sugars were in the fractions of the three alcoholic extracts. The extracts were subjected to high-performance liquid chromatography (HPLC), and the soluble carbohydrate profile was determined. We measured sugars such as raffinose, sucrose, stachyose, glucose, fructose and also cyclitols (Garcia et al., 2006).

Experimental design and statistical analysis: The experiment was completely randomized and consisted of four replications of 50 seeds per experimental unit in a $4 \times 5$ factorial design (desiccation levels of 31, 19, 12 and $5 \%$ and $\mathrm{GA}_{4+7}+\mathrm{CK}$ concentrations of $0,250,500,750$ and $1000 \mathrm{mg} \mathrm{L}^{-1}$ ).

The electrical conductivity experiment was also completely randomized. This experiment also consisted of four replications of 50 seeds per experimental unit. The treatments corresponded to the different levels of desiccation.

Data were subjected to analyses of variance (F-test). The means were compared with the Tukey's test at a threshold of $p<0.05$ (Gomes, 1990; Mischan and Pinho, 1996). 


\section{RESULTS}

Freshly extracted $A$. emarginata seeds showed $31 \%$ of water content (WC) and $54,5 \%$ of germination percentage G (\%), which was not affected by reducing WC to $12 \%$ (Table 1). Considering that seeds with $5 \%$ WC showed $35 \%$ of $\mathrm{G}(\%)$, these seeds were considered tolerant to desiccation (Table 1). Electrical conductivity (EC) of desiccated seeds was similar to that of the nondesiccated seeds (Table 2). However, reduction in G (\%) observed for the seeds with 5\% WC should be further investigated. The trends on the germination frequency graphs indicated that germination in distilled water could be expected despite seed desiccation.

Mean germination time ranged from 24 days in seeds with $31 \%$ water content to 16 days in seeds with 19,12 and $5 \%$ water content (Figure 1). However, no statistically significant differences were noted in the mean germination time (MGT) (Table 1).

The sugar profile analysis (Table 3 ) indicated that the sugar content varied as the seed water content was reduced. As WC decreased from 19 to $5 \%$, the glucose and fructose concentration also decreased, and sucrose concentration increased. The cyclitol concentration remained unaltered (Table 3 ) and only traces of raffinose and stachyose were identified in the seeds, regardless of water content.
Seeds without drying ( $31 \%$ WC) germinated in a less uniform way when they were immersed in 250 and $500 \mathrm{mg} \mathrm{L} \mathrm{L}^{-1}$ of the plant growth regulator $\mathrm{GA}_{4+7}+\mathrm{CK}$. However, the administration of plant growth regulators did not change the rate of germination in the other seeds that underwent artificial desiccation.

In addition to increasing the germination rate, plant growth regulators also reduced MGT and increased the germination speed for seeds that underwent or not artificial desiccation (Table 1).

The data collected on the frequency and uniformity of germination indicated that we could expect germination to occur when plant growth regulators were applied to the A. emarginata seeds (Figure 2). On average, 250 to $750 \mathrm{mg} \mathrm{L}^{-1}$ of the growth regulators were sufficient to synchronize germination. In contrast, there was no difference in synchronization between the seeds with different water contents (Table 4).

Table 2. Electrical conductivity (E.C.) of $A$. emarginata seeds subjected to different levels of desiccation

\begin{tabular}{lc}
\hline Water Content (\%) & E.C. $\left(\boldsymbol{\mu} \mathbf{S} \mathbf{~ c m}^{2} \mathbf{~ g}^{-1}\right)$ \\
\hline 31 & $0.083 \mathrm{ab}$ \\
19 & $0.080 \mathrm{~b}$ \\
12 & $0.098 \mathrm{a}$ \\
5 & $0.093 \mathrm{ab}$ \\
C.V $(\%)$ & 6.75 \\
\hline
\end{tabular}

The mean values followed by the same letter do not differ according to Tukey's test at $p<0.05$.

Table 1. Germination [G (\%)], mean germination time [MGT (days)] and germination speed index (GSI) of $A$. emarginta seeds subjected to different levels of desiccation and concentrations of $\mathrm{GA}_{4+7}+\mathrm{CK}$.

\begin{tabular}{|c|c|c|c|c|c|}
\hline \multirow{2}{*}{ Water content (\%) } & \multicolumn{5}{|c|}{$\mathrm{GA}_{4+7}+\mathrm{N}-\left(\right.$ phenylmethyl)-aminopurine $\left(\mathrm{mg} \mathrm{L}^{-1}\right)$} \\
\hline & 0 & 250 & 500 & 750 & 1000 \\
\hline & \multicolumn{5}{|c|}{ G (\%) } \\
\hline 31 & 54.5 a BC & 70.5 a $\mathrm{A}$ & 70.5 a $\mathrm{A}$ & 67.5 a $A B$ & 53.0 a C \\
\hline 19 & 55.5 a $A B$ & 61.0 a $\mathrm{A}$ & 68.0 a $\mathrm{A}$ & $46.0 \mathrm{~b} \mathrm{~B}$ & 44.0 a B \\
\hline 12 & 57.5 a $A B$ & $43.5 \mathrm{~b} \mathrm{~B}$ & $45.0 \mathrm{~b} \mathrm{~B}$ & 70.0 a A & 55.0 a B \\
\hline 5 & $35.0 \mathrm{~b} \mathrm{~A}$ & $39.0 \mathrm{~b} \mathrm{~A}$ & $36.5 \mathrm{~b} \mathrm{~A}$ & $28.0 \mathrm{c} \mathrm{A}$ & $26.0 \mathrm{~b} \mathrm{~A}$ \\
\hline \multirow[t]{2}{*}{ C.V. $(\%)$} & \multicolumn{5}{|c|}{13.93} \\
\hline & \multicolumn{5}{|c|}{ MGT (days) } \\
\hline 31 & $25.50 \mathrm{a} A$ & $21.00 \mathrm{a} \mathrm{B}$ & $21.75 \mathrm{a} \mathrm{B}$ & $22.00 \mathrm{a} \mathrm{B}$ & $22.00 \mathrm{ab} \mathrm{B}$ \\
\hline 19 & 25.25 a A & 21.25 a BC & $19.75 a b C$ & $20.75 a b C$ & 23.50 a $A B$ \\
\hline 12 & $24.25 \mathrm{a} A$ & 20.25 a B & 19.50 b B & 19.75 b B & 20.00 b B \\
\hline 5 & $21.50 \mathrm{~b} \mathrm{~A}$ & $17.50 \mathrm{~b} \mathrm{C}$ & 18.75 b BC & $20.00 \mathrm{ab} A B$ & $20.25 \mathrm{~b} A B$ \\
\hline \multirow{2}{*}{ C.V. $(\%)$} & \multicolumn{5}{|c|}{5.66} \\
\hline & \multicolumn{5}{|c|}{ GSI } \\
\hline 31 & $14.00 \mathrm{a} \mathrm{B}$ & $25.25 \mathrm{~b} \mathrm{AB}$ & $27.25 \mathrm{ab} A B$ & $29.25 \mathrm{a} \mathrm{A}$ & $26.25 \mathrm{~b} \mathrm{Ab}$ \\
\hline 19 & $11.25 \mathrm{a} \mathrm{B}$ & 28.75 b A & $24.00 \mathrm{ab} A B$ & 29.75 a A & $13.75 \mathrm{bc} B$ \\
\hline 12 & 19.5 a BC & 16.50 b C & $32.25 \mathrm{a} \mathrm{B}$ & 26.25 a BC & 54.75 a $\mathrm{A}$ \\
\hline 5 & 18.75 a B & 45.75 a A & 14.75 b B & 10.00 b B & 11.25 C B \\
\hline C.V. $(\%)$ & & & 29.58 & & \\
\hline
\end{tabular}

The mean values followed by the same lower case letters in the columns and upper case letters in the rows do not differ according to Tukey's test at $p<0.05$.

Braz. J. Plant Physiol., 24(4): 253-260, 2012 


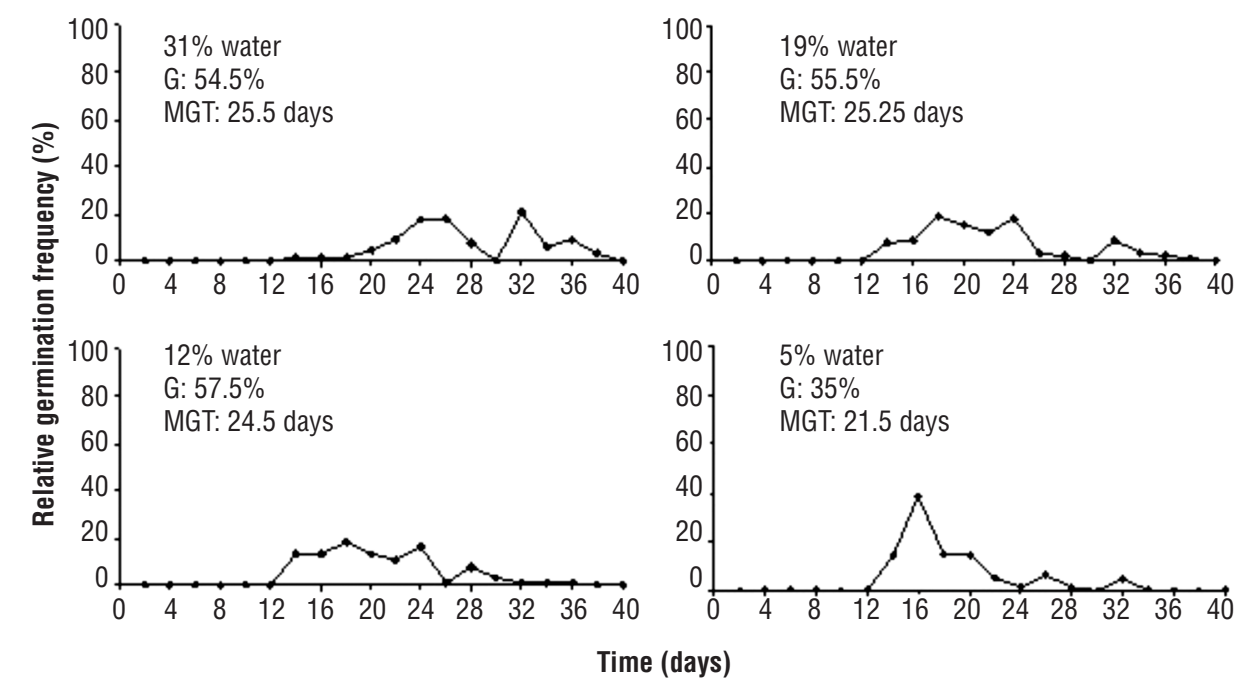

Figure 1. Relative germination frequency of the "araticum-de-terra-fria" (Annona emarginata (Schldtl.) H. Rainer) seeds with different water contents. The seeds were immersed in distilled water. MGT, mean germination time. G, germination (\%).
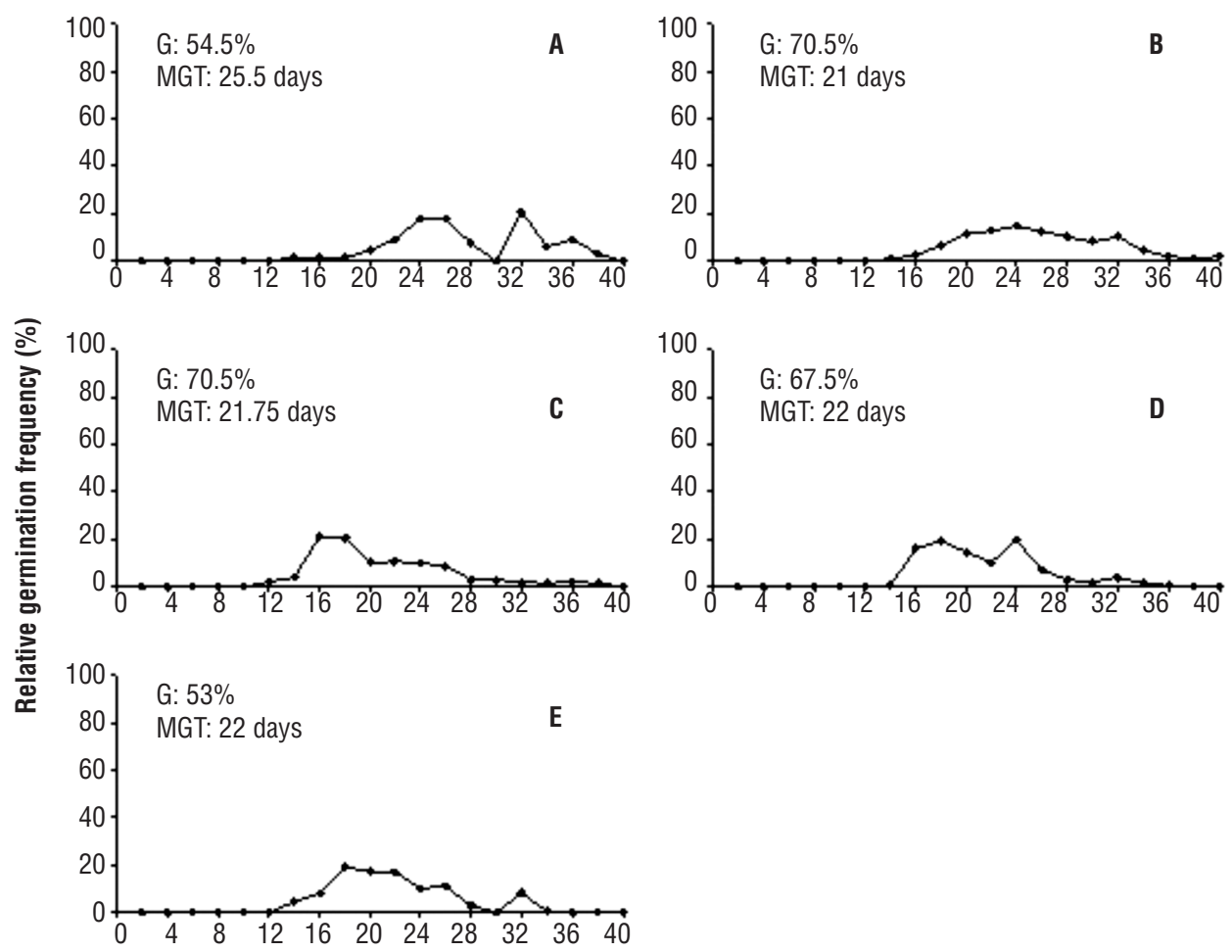

\section{Time (days)}

Figure 2. Relative germination frequency of the "araticum-de-terra-fria" (Annona emarginata (Schldtl.) H. Rainer) seed germination. The seeds had normal water content $(31 \%)$ and were soaked in different concentration of $\mathrm{GA}_{4+7}$ and $\mathrm{N}$-(phenylmethyl)-aminopurine: (A) $0 \mathrm{mg} \mathrm{L}^{-1}$, (B) $250 \mathrm{mg} \mathrm{L}^{-1}$, (C) $500 \mathrm{mg} \mathrm{L}^{-1}$, (D) $750 \mathrm{mg} \mathrm{L}^{-1}$, (E) $1000 \mathrm{mg} \mathrm{L}^{-1}$. MGT, mean germination time. G, germination (\%). 
Table 3. Soluble sugar contents (mg g-1 dry mass) of "araticum-de-terra-fria" (Annona emarginata (Schltdl.) H. Rainer) intact seeds subjected to different levels of desiccation.

\begin{tabular}{lclcc}
\hline Water content (\%) & Cyclitols & Glucose & Fructose & Sucrose \\
\hline 31 & $8.63 \mathrm{a}$ & $83.06 \mathrm{a}$ & $27.88 \mathrm{a}$ & $3.07 \mathrm{c}$ \\
19 & $6.55 \mathrm{a}$ & $55.90 \mathrm{~b}$ & $16.18 \mathrm{~b}$ & $57.98 \mathrm{a}$ \\
12 & $6.62 \mathrm{a}$ & $65.17 \mathrm{ab}$ & $19.27 \mathrm{~b}$ & $57.24 \mathrm{a}$ \\
5 & $5.76 \mathrm{a}$ & $43.42 \mathrm{~b}$ & $15.65 \mathrm{~b}$ & $47.30 \mathrm{~b}$ \\
C.V $(\%)$ & 35.61 & 20.33 & 16.64 & 7.7 \\
\hline
\end{tabular}

The mean values followed by the same letter do not differ according to Tukey's test at $p<0.05$.

Table 4. Uniformity index (U) and estimated percentage of dormant seeds at the end of the germination test of $A$. emarginata seeds subjected to different levels of desiccation and concentrations of $\mathrm{GA}_{4+7}+\mathrm{CK}$.

\begin{tabular}{|c|c|c|c|c|c|c|}
\hline \multirow{2}{*}{ Water Content (\%) } & \multicolumn{5}{|c|}{$\mathrm{GA}_{4+7}+\mathrm{N}$-(phenylmethyl)-aminopurine $\left(\mathrm{mg} \mathrm{L}^{-1}\right)$} & \multirow{2}{*}{ Means } \\
\hline & 0 & 250 & 500 & 750 & 1000 & \\
\hline \multicolumn{7}{|c|}{ Synchronization (U) } \\
\hline 31 & 2.63 & 3.15 & 3.03 & 2.76 & 2.77 & $2.9 \mathrm{a}$ \\
\hline 19 & 2.92 & 3.07 & 3.12 & 2.78 & 2.58 & $2.95 \mathrm{a}$ \\
\hline 12 & 2.73 & 2.84 & 2.97 & 2.97 & 2.65 & $2.9 \mathrm{a}$ \\
\hline 5 & 2.34 & 2.73 & 2.74 & 2.61 & 2.82 & $2.75 \mathrm{a}$ \\
\hline Means & $2.62 \mathrm{~B}$ & $2.93 \mathrm{~A}$ & $3.00 \mathrm{~A}$ & $2.93 \mathrm{~A}$ & $2.87 \mathrm{AB}$ & \\
\hline \multicolumn{7}{|c|}{ Dormant (\%) } \\
\hline 31 & $2.00 \mathrm{~b} \mathrm{~A}$ & $3.00 \mathrm{~b} \mathrm{~A}$ & $1.00 \mathrm{aA}$ & $1.00 \mathrm{a} A$ & 3.00 a A & 2.00 \\
\hline 19 & $1.50 \mathrm{~b} \mathrm{~A}$ & $2.00 \mathrm{~b} \mathrm{~A}$ & $1.00 \mathrm{a} \mathrm{A}$ & 2.50 a $A$ & $1.00 \mathrm{a} \mathrm{A}$ & 1.90 \\
\hline 12 & 11.50 a A & 4.50 b B & $4.00 \mathrm{aB}$ & $2.50 \mathrm{a} B$ & $1.00 \mathrm{a} \mathrm{B}$ & 4.10 \\
\hline 5 & $3.00 \mathrm{~b} \mathrm{~B}$ & 1.50 a $\mathrm{A}$ & $1.00 \mathrm{aB}$ & $2.00 \mathrm{a} B$ & $2.50 \mathrm{a} \mathrm{B}$ & 5.30 \\
\hline Means & 4.50 & 7.00 & 1.50 & 2.00 & 1.62 & \\
\hline
\end{tabular}

The mean values followed by the same lower case letters in the columns and upper case letters in the rows do not differ according to Tukey's test at $p<0.05$.

\section{DISCUSSION}

A protective mechanism must guarantee cell membrane integrity (Nakada et al., 2010). Thus, the knowledge of the seed water content before seed dispersion is important for developing effective strategies to maintain seed viability and longevity (Berjak and Pammenter, 2008). Tokunaga (2000) asserted that $A$. emarginata seeds should be sown immediately after extraction from the fruit because they quickly lose viability when dried and stored. However, in the present study we showed that these seeds are still viable after their water content was reduced to $12 \%$, indicating that seeds of $A$. emarginata appear to be desiccation tolerant. Therefore, a considerable amount of water can be removed from the A. emarginata seeds without the complete loss of germination potential. This characteristic allows us to develop strategies for species seeding and production more than once a year, as suggested by Berjak and Pammenter (2008).

Our results are consistent with those reported by Carvalho et al. (2001) for Annona glabra L., which is tolerant to desiccation and freezing, that is typical for orthodox seeds. This tolerance was also observed in the present study in A. emarginata seeds. Carvalho et al. (2001) observed that $90 \%$ of the seeds germinated, regardless of water content. However, germination remained slow and uneven after desiccation. In contrast, we expected the A. emarginata seeds to germinate, but the germination that we observed was also uneven.

Leduc et al. (2012) reported increased sucrose concentration with desiccation induced by PEG (polyethylene glycol) in the embryos and cotyledons of Caesalpinia echinata $\mathrm{L}$. In the intact seeds of $A$. emarginata, sucrose content also appears to relate to desiccation, since sucrose concentration increased with the decrease in WC (19 to 5\% of water). According to Kingel and Galili (1995), a combination of oligosaccharides and sucrose is more effective than sucrose alone for protecting cells from desiccation. The authors emphasized the importance of the raffinose sugars, including raffinose, stachyose and verbascose. This study identified only traces of raffinose or stachyose in the 
A. emarginata seeds. Therefore, the present cyclitols could also function similarly to the seeds of this work since it is present throughout the drying process (Table 3).

Garcia et al. (2006) observed that Caesalpinia echinata seeds also contain low concentrations of raffinose and stachyose, like $A$. emarginata seeds. The role of raffinose and stachyose in this species could be played by cyclitols, which exhibit high concentration at the end of seed maturation (Borges et al., 2006). According to Peterbauer and Richter (2001), free cyclitols can accumulate in seeds and contribute to the structural stability of organelles, membranes and enzymes. Cyclitols also contribute to the formation of the vitreous state. The same reasoning may be applied to the $A$. emarginata seeds. Cyclitols were identified in the seeds, regardless of water content. The cyclitol concentration did not vary with desiccation. Thus, these sugars may contribute to cell stability.

Applying the plant growth regulators gibberellin and cytokinin generally reduced the mean time to the completion of germination (Hertweck, 2008). Gibberellins 4 and 7 are known to be the most active growth regulators. Cytokinins are involved in many physiological processes. They withdraw seeds from dormancy and promote germination, especially when combined with other promoting agents, including gibberellins (Reeve and Crozier, 1974; Khan, 1975; Socolowski and Cicero, 2011).

Active gibberellins, in turn, block the expression of genes that repress germination (RGL2, SPY) and increase seed germination potential (Peng and Harberd, 2002). Therefore, the exogenous administration of active gibberellins during germination increases the growth potential of the embryo by promoting the degradation of seed reserves to provide energy for growing embryo and seedling (Koornneef, 2002). Endogenous gibberellins are synthesized during seed imbibition and promote the synthesis of hydrolytic enzymes that degrade reserves and modify cell walls. These processes weaken the endosperm enabling radicle protrusion through the integument and completion of germination per se (Harberd, 2002).

Previous studies have also described exogenous plant growth regulators that affect development in Annonaceae seeds. The purpose of these studies was to develop strategies to promote germination in species that can be used as rootstocks. A. emarginata is one of such species. Campbell and Popenoe (1968) achieved a 77\% germination rate using $350 \mathrm{mg} \mathrm{L}^{-1}$ of $\mathrm{GA}_{3}$ on Annona cherimola Mill seeds. Ferreira (2011) observed that the exogenous administration of gibberellins and cytokinins to $A$. diversifolia and $A$. purpurea seeds increased their germination rates.
These rates ranged from 50 to $77 \%$ in $A$. diversifolia and from 18 to $30 \%$ in $A$. purpurea when 200 to $1000 \mathrm{mg} \mathrm{L}^{-1}$ of $\mathrm{GA}_{4+7}+$ benzyladenine (BA) was applied.

In addition, Socolowski and Cicero (2011) observed that applying $500 \mathrm{mg} \mathrm{L}^{-1}$ of $\mathrm{GA}_{4+7}+6$-BA induced $70 \%$ of the Xylopia aromatic seeds to emerge from dormancy. These researchers also observed shorter mean germination time after this intervention. We have observed similar results in $A$. emarginata seeds. Using the three plant growth regulators in combination promotes germination through mechanisms involving seed metabolism. The promoters (gibberellins and cytokinins) are favored over the inhibitors (abscisic acid). Cavalcanti et al. (2007) also reported the germination rate of Annonaceae seeds increased with plant growth regulators. These authors immersed the seeds in $250 \mathrm{mg} \mathrm{L}^{-1}$ of $\mathrm{GA}_{3}$. They found that the growth regulator helped the Annona crassiflora seeds to emerge from dormancy and promoted germination in the $A$. emarginata seeds.

Seeds of $A$. emarginata appear to be desiccation tolerant, since germination is not altered and sucrose content increases when seed water content is reduced to values as low as $12 \%$. Exogenous $\mathrm{GA}_{4+7}+\mathrm{N}$-(phenylmethyl)aminopurine improves its germinability.

\section{REFERENCES}

Barbedo CJ, Bilia DAC, Figueiredo-Ribeiro RC (2002) Tolerância à dessecação e armazenamento de sementes de Caesalpinia echinata Lam. (pau-brasil), espécie da mata atlântica. Rev. Bras. Bot. 4:431-439.

Barbedo CJ, Cicero SM (1998) Utilização do teste de condutividade elétrica para previsão do potencial germinativo de sementes de ingá. Sci. Agric. 2:249-259.

Bewley, JD, Bradford, K, Hilhorst, H, Nonogaki, H (2013) Seeds: physiology of development, germination and dormancy. Springer, New York.

Berjak P, Pammenter NW (2008) From Avicennia to Zizania: seed recalcitrance in perspective. Ann. Bot. 101:213-28:1-16.

Black M, Pritchard HW (2002) Desiccation and survival in plants. Drying without dying. CABI Publishing, Wallingford, UK.

Bonaventure L (1999). El cultivo de la chirimoya e de su híbrido atemoya em Brasil. In: Proceedings of the First International Symposium on Cherimoya, Loja, Equador. Acta Hortic. 497:147-151.

Borges IF, Barbedo CJ, Richter AA, Figueiredo-Ribeiro RCL (2007) Variations in sugars and cyclitols during development and maturation of seeds of Brazilwood (Caesalpinia echinata Lam., Leguminosae). Braz. J. Plant Physiol. 18:475-482.

Brasil (2009). Ministério da Agricultura, Pecuária e Abastecimento. Secretaria de Defesa Agropecuária. Regra de Análise de Sementes. Brasília: Mapa/ACS. 399 p. 
Campbell CW, Popenoe J (1968) Effect of gibberellic acid on seed dormancy of Annona diversifolia saff. Proc. Trop. Reg. Am. Soc. Hort. Sci. 11:31-36.

Carvalho NM, Nakagawa J (2000) Sementes: ciência, tecnologia e produção. Funep, Jaboticabal.

Carvalho JEU, Nascimento WMO, Muller CH (2001) Tolerância de sementes de araticum-do-brejo (Annona glabra L.) ao dessecamento e ao congelamento. Rev. Bras. Frutic. 23:179-182.

Costa PN (2009) Reguladores vegetais, luz e temperatura na germinação de sementes de araticum-de-terra-fria (Annona emarginata (Schltdl.) H. Rainer). Botucatu, Universidade Estadual Paulista. Master's Thesis.

Costa PN, Bueno SSC, Ferreira G (2011) Fases da germinação de sementes de Annona emarginata (Schltdl.) H. Rainer em diferentes temperaturas. Rev. Bras. Frutic. 33:253-260.

Durda F, Uhlmann A, Pescador R (2007) Dosagem de carboidratos nas sementes de Shizolobium parahyba e Talauma ovata de acordo com 0 tamanho seminal. Rev. Bras. Biocienc. 5:465-467.

Ferreira G (2011) Reguladores vegetais na superação da dormência, balanço hormonal e degradação de reservas em sementes de Annona diversifolia Saff. e A. purpurea Moc. \& Sessé ex Dunal (Annonaceae). Botucatu, Universidade Estadual Paulista. Tese de Livre-Docência.

Ferreira G, Erig PR, Moro E (2002) Uso de ácido giberélico em sementes de fruta-do-conde (Anona squamosa L.) visando à produção de mudas em diferentes embalagens. Rev. Bras. Frutic. 24:178-182.

Ferreira G, Guimarães VF, Pinho SZ, Oliveira MC, Richart A, Braga JF, Dias GB (2006) Curva de absorção de água em sementes de atemóia (Annona cherimola Mill. x Annona squamosa L.) cv. 'Gefner'. Rev. Bras. Frutic. 28:121-124.

Garcia IS, Souza A, Barbedo CJ, Dietrich SMC, Figueiredo-Ribeiro RCL (2006) Changes in soluble carbohydrates during storage of seeds of Caesalpinia echinata Lam. (Brazilwood), an endangered leguminous tree from the Brazilian Atlantic Forest. Braz. J. Biol. 66:739-745.

Gomes FP (1990) Curso de Estatística Experimenta. Nobel, São Paulo.

Hoekstra FA, Golovina EA, Buitink J (2001) Mechanisms of plant desiccation tolerance. Trends Plant Sci. 6:431-438.

José AC, da Silva EAA, Davide AC, Melo AJS, Toorop PE (2011) Effects of drying rate and storage time on Magnolia ovata Spreng seed viability. Seed Sci. Technol. 39:425-434.

Khan AA (1975) Primary, preventive and permissive roles of hormones in plant systems. Bot. Rev. 41:391-420.

Kavati R0, Bueno SCS, Tokinaga T, Nogueira EMC, Takassaki J, Periot NW (1997) A cultura da atemóia (Annona cherimola Mill. x Annona squamosa L.). SAA/CATI, Campinas. 22 p.

Kigel J, Galili G (1995) Seed development and germination. Plenum, New York.

Koster KL, Leopold AC (1988) Sugars and desiccation tolerance in seeds. Plant Physiol. 88:829-832.

Koornneef M (2002) Seed dormancy and germination. Curr. Opin. Plant Biol. 5:33-36.

Labouriau LG (1983) A germinação das sementes. Secretaria Geral da Organização dos Estados Americanos, Washington. 174 p.
Mischan MM, Pinho SZ (1996) Experimentação Agronômica - Dados não balanceados. Fundibio, Botucatu.

Moore JP, Le NT, Brandt WF, Driouich A, Farrant JM (2009) Towards a systems-based understanding of plant desiccation tolerance. Trends Plant Sci. 14:110-107.

Oliveira MC, Ferreira G, Guimarães VF, Dias GB (2010) Germinação de sementes de atemóia (Annona cherimola Mill. x Annona squamosa L.) cv. 'Gefner' submetidas à tratamentos com ácido giberélico $\left(\mathrm{GA}_{3}\right)$ e ethephon. Rev. Bras. Frutic. 32:544-554.

Pammenter NW, Berjak P (2000) Evolutionary and ecological aspects of recalcitrant seed biology. Seed Sci. Res. 10:301-306.

Pawshe YH, Patil BN, Patil LP (1997) Effect of pregermination seed treatment on the germination and vigour of seedlings in custard apple (Anona squamosa L.). Ann. Plant Physiol. 11:150-154.

Peng J, Harberd NP (2002) The role of GA-mediated sinaling in the control of seed germination. Curr. Opin. Plant Biol. 5:376-381.

Peterbauer T, Richter A (2001) Biochemistry and physiology of raffinose family oligosaccharides and galactosyl cyclitols in seeds. Seed Sci. Res. 11:185-197.

Rainer H (2007) Monographic studies in the genus Annona L. (Annonaceae): Inclusion of the genus Rollinia A.ST.-Hil. Ann. Nathurhist. Mus. Wien. 108:191-205.

Ranal, MA, Santana, DG (2006) How and why to measure the germination process? Rev. Bras. Bot. 29:1-11.

Reeve DR, Crozier A (1974) An assessment of gibberellin structureactivity relationships. J. Exp. Bot. 25:431-445.

Roberts, EH (1973) Predicting the storage life of seeds. Seed Sci. Technol. 1:499-514.

Silva, JB, Nakagawa, J (1995). Estudos de fórmulas para cálculo de velocidade de germinação. Informativo Abrates 5:62-73.

Smet S, Damme PV, Scheldeman X, Romero J (1999) Seed structure and germination of cherimoya (Annona cherimola Mill.). Acta Hortic. 497:269-278.

Socolowski F, Cicero SM (2011) Use of growth regulators to overcome seed dormancy in Xylopia aromatica (Annonaceae). Seed Sci. Technol. 39:21-28.

Steadman KJ, Burgoon MS, Schuster RL, Lewis BA, Edwardson SE, Obendorf RL (2000) Fagopyritols, D-chiro-inositol and other soluble carbohydrates in buckwheat seed milling fractions. J. Agric. Food Chem. 48:2843-2847.

Stenzel NMC, Murata IM, Neves CSVJ (2003) Superação da dormência em sementes de atemóia e fruta-do-conde. Rev. Bras. Frutic. 25:305-308.

Tokunaga T (2000) A cultura da Atemóia. CATI, Campinas. 80p.

Uemura M, Steponkus PL (2003) Modification of the intracellular sugar content alters the incidence of freeze-induced membrane lesions of protoplasts isolated from Arabidopsis thaliana leaves. Plant Cell Environ. 26:1083-1096.

Vieira R.D, Krzyzanowski F.C. (1999). Teste de condutividade elétrica. In: Krzyzanowski FC, Vieira RD, França Neto JB (eds), Vigor de Sementes: conceitos e testes, cap. 4, pp.1-26. ABRATES, Londrina, Brasil.

Walters C (2000) Levels of recalcitrance in seeds. Rev. Bras. Fisiol. Veg. 12:7-21. 